\title{
Technological competencies in cardiovascular nursing education
}

\author{
As competências tecnológicas no ensino de enfermagem cardiológica \\ Las competencias tecnológicas en la enseñanza de la enfermería cardiológica
}

Rika Miyahara Kobayashi¹,2, Maria Madalena Januário Leite ${ }^{1}$

${ }^{1}$ Universidade de São Paulo, Escola de Enfermagem, Departamento de Orientação Profissional, São Paulo, SP, Brazil.

${ }^{2}$ Instituto Dante Pazzanese de Cardiologia, Serviço de Educação Continuada, São Paulo, SP, Brazil.

\begin{abstract}
Objective: To identify the perception of the coordinators of the Specialization Courses in Cardiovascular Nursing about inserting content from Information and Communication Technology (ICT) and analyze them in relation to the technological competencies and regarding its applicability, relevance and importance in assisting, teaching and management. Method: Descriptive study with 10 coordinators of the Specialization course in Cardiologic Nursing, who replied to the questionnaire for the development of technological competency adapted from the Technology Initiative Guidelines Education Reforms (TIGER), and analyzed using the Delphi technique for obtaining consensus and scored according to the relevance, pertinence and applicability using Likert scale according to degree of agreement. Results: Six courses developed ICT content. The contents of the TIGER were considered relevant, pertinent and applicable. Conclusion: The coordinators recognize the need for technological competencies of the Cardiovascular Nurse for healthcare applicability.
\end{abstract}

DESCRIPTORS

Nursing Informatics; Computer Literacy; Cardiovascular Nursing; Information Technology; Education, Nursing, Graduate. 


\section{INTRODUCTION}

Health information policy has been discussed and normalized over almost four decades. However, we have to advance in the legitimation of this health information guideline as a collective construction and implementation in the field of healthcare in terms of using information in health, to information technology, to quality of information and ethics related to health information ${ }^{(1)}$.

One of the forms of legitimation takes place through the access to information, which can be favored by the educational process. With regard to the Informatics education, specifically in Nursing, it was found that, in Brazil, computers were introduced in the profession more than 40 years ago, and the first publications, in early 1980s, occurred when the Universities and Public Schools of Nursing initiated the use of Information and Communication Technologies (ICT) teaching and learning for clinics, management, teaching and research and when the construction of computing systems applied to teaching was also described ${ }^{(2-3)}$.

From the 1990s, greater need for including informatics in the undergraduate syllabus was evidenced ${ }^{(3)}$, which took place in a theoretical and practical manner, developing basic skills. During the same decade, students also considered the inclusion of this class in undergraduate Nursing Courses, aiming to encourage learning.

In the decade of 2000, the teaching of informatics valued the relations of ICT with the professional practice of health worker, with a view to professional qualification and the production impact with their professional performance ${ }^{(4)}$.

However, in the decade of 2010 low availability of this class at undergraduate level has been observed, contrary to trends in the labor market and the National Curriculum Guidelines of the Nursing Undergraduate Courses, which determined the need to provide students with competencies and access to proper use of the new ICTs ${ }^{(5-6)}$.

This gap in the training of undergraduates may have caused consequences, as when considering the use of internet by Nursing students, research found they have informatics knowledge for academic use ${ }^{(7)}$ and $58.3 \%$ of nurses at training, who had intermediate level of fluency in informatics, reported not having experienced the applicability of technologies in nursing practice during their training ${ }^{(8)}$.

The low level of informatics knowledge of the students enrolled in undergraduate courses demonstrated the necessity for the introduction of computer use in the training of these new professionals, in order to subsequent adaptation to the labor market ${ }^{(9)}$.

These notes sign the need for involvement and training of teachers, changes in posture of academic and institutional investments, as well as monitoring the use of resources involving $\mathrm{ICT}^{(10)}$.

In the work environment, nurses not belonging to the contemporary generation, those not belonging to the digital age, require training in this field by means of permanent education, also through specialization courses that promote the development of technological competence. In this sense, Graduate courses should also require to include the technological competencies as one of the priorities of professional development.

The authors of the Informatics Competencies Collaborative Team (TICC) of the Technology Initiative Guidelines Education Reforms (TIGER) developed recommendations on Informatics for nurses and nursing students. The nurses were expected to engage in information systems and technologies in order to develop evidence-based healthcare, using tools that subsidize decision-making at the clinic and health electronic records, seeking to ensure quality and safety in patient care ${ }^{(11)}$.

There is evidence that studies on the basic competencies in Informatics for nurse managers related to information management, communication, documentation, education, monitoring, to mastering software and information systems, to the knowledge of data, impact, privacy and security, rules of use and maintenance of systems have been performed ${ }^{(12)}$.

In Brazil, specific studies about the competencies and the use of technologies in the cardiovascular area are still scarce, which also justifies the performance of this study.

The teaching mode choice of Specialization and Residence in this study is justified by the curricular organization focused on specialized practice, with facilitation for the specific work in a determined area of knowledge. More specifically in relation to the teaching mode of the Residence, which provides training of human resources with $80 \%$ of the working hours in practical service, which can reduce distances between education and work.

On the other hand, the choice of Cardiovascular Nursing is justified by the increase of $107 \%$ of the population of elderly between 1980 and 2000, with a future projection, for the next 20 years, of an increase from $8 \%$ to $15 \%$ of this population. There are also the increased costs of hospital expenses due to chronic diseases, among them, Cardiology in SUS, totaling about $75 \%$ of healthcare costs. And finally, last but not least, cardiologic diseases are the leading cause of death in the country, representing $30 \%$ of the total in 2008 , being estimated 23.6 million a year for $2030^{(13-14)}$.

With these statistical evidences about the harms to cardiovascular health, longevity of citizens, the need for structured institutionalized care in public service networks, and the need for training of human resources able to meet this demand in line with the technological advances in the world of work, this study had as its objectives: to identify the perception of the coordinators of the specialization or residence courses in cardiovascular Nursing regarding insertion of content in information and communications technology (ICT); to analyze the content described by coordinators in relation to competencies relating to information and communication technologies and analyze the applicability, pertinence and relevance of the content recommended by the TIGER, according to the perception of the coordinators.

\section{METHOD}

Exploratory, descriptive study, developed along with the coordinators of the Specialization Courses in Cardiovascular Nursing of Sao Paulo city and Residence in Cardiovascular Nursing in the country. It was submitted and approved 
by the Ethics and Research Committee under the Protocol number 4226/2013.

To identify the educational institutions and Graduate programs, Specialization and Residence courses in Cardiovascular Nursing, registered, we accessed the website of the Brazilian Ministry of Education, in the first semester of 2013.

For inclusion in the study, we conducted an online search of the courses, having been identified nine Specialization Courses and six Residence Courses in Cardiovascular Nursing. The courses that had not graduated any classes yet and those which had not consented to participate were excluded. The sample was composed by six Specialization Courses from the State of Sao Paulo and four Residence Courses in the country, the latter distributed among the following States: Rio de Janeiro (1), Sao Paulo (1) and Pernambuco (2).

For data collection, a questionnaire was elaborated with the characteristics of the course, the respondent, the respondent's perception regarding the inclusion of ICT content in the courses, and the analysis of the pertinence, relevance and applicability of the content of ICT in teaching, management and healthcare.

The list of content that was inserted in the questionnaire was adapted from the competencies model from TIGER. The choice of this model was a result of studies conducted by the authors of the Informatics Competencies Collaborative Team (TICC) of Technology Initiative Guidelines Education Reforms (TIGER), who had developed recommendations on Informatics for Nurses and Nursing students ${ }^{(14)}$.

Among the collaborative teams, there is a team of Informatics Competencies, which helped us develop the minimum set of skills that students need to develop for their practice nowadays ${ }^{(15)}$.

This standardization aimed to harmonize and determine a set of informatics competencies for all levels of education in Nursing, to its practice, to defend and support its inclusion, standardization and documentation in certified Nursing Specialties. To this end, there are three categories for informatics competencies: computer competence, informational competence and information management.

The contents proposed for the development of basic competence were: Concepts of Information and Communication Technology; using the computer and managing files (word processor, spreadsheets, presentations), use of databases, navigation and communication on the web.

On "informational competence", the contents included the determination of the nature and extent of the information, the need for effective and efficient access, evaluation of information and sources, incorporating selected information to their knowledge and system value, performing specific proposal for effective individual or collective use and evaluate the results of the use of this information.

Finally, in the competence of information management, it was proposed the approach of concepts about health information system, confidentiality, access control and related security information, to navigation, to documents, to decision making and reporting, and on the principles of policy and informational procedures ${ }^{(15)}$.
This construction performed by the TIGER, which defined the informatics contents and the competencies of nurses in ICT, subsidized the construction of the questionnaire.

The contents worked for the development of Basic Competencies, Information and Information Management were evaluated by the coordinators, in a growing numerical scale from 0 to 10 . The score given by the coordinators of the courses was tabulated and the Delphi Technique was used $^{(16)}$ to reach the agreement between the results of valuations pointed by the coordinators.

The values were systemized and classified into four categories, described as: strongly disagree (0 to 2.5 points) somewhat disagree (2.5 to 5 points), somewhat agree (5 to 7.5 points) and strongly agree ( 7.5 to 10 points), seeking to know the degree of agreement of nurses regarding pertinence (validity), relevance (importance) and applicability, for each content that composes the list of ICT competencies.

\section{RESULTS}

Through the profile of the 10 respondents, we know they were all had a degree in Nursing, with Specialization Certificates, some with more than one specialization, eight with a Master's degree, six with $\mathrm{PhD}$, one Postdoctoral fellow and one full-professor. In the positions taken, eight were coordinators, the average weekly hours devoted to Residence was of 12 hours, ranging from 4 to $84 \mathrm{~h} /$ week, working time in the institution varied from 3 to 40 years, the time in the position ranged from 3 and 28 years, and working time in the course varied between 2 and 25 years.

In relation to the profile of the course, three Residence courses were public launched between 1980 and 2007, enrolling three to 26 students, with seven or more than 20 graduated classes, with 5760 hours of course, distributed in 60 hours per week. From the Specialization Courses, five were private, launched between 2004 and 2010, with one to 20 classes graduated and a number of students ranging from 15 to 80 per class, with 360 to 420 hours from 1 to 3 days per week on a part-time or full-time scheme once a week.

With regard to the profile of the student, in both courses was described as being nurses, with technical and scientific knowledge in the specific cardiovascular area to cardiovascular patient's healthcare of greater complexity and their family, active mainly in healthcare and/or management in secondary and tertiary services, and in the profile of resident described the need of research as being one of the competencies required.

Concerning the ICT contents, six of the courses (one Residence and five Specializations) replied that the topic was approached, and four (three of Residence and one Specialization), no. From those who used an approach for ICT, reported that the technological resources were used in an integrated manner on classes of research methodology, teaching, management of nursing services, diagnostic and therapeutic support, but not as a specific class.

The resources used for this approach were the interactive media (20), such as conferences, forums, chat, email, social networking, wiki, Virtual Learning Environments (nine), and others (simulators, informative reports, text editors). 
With regard to the contents, the extent of agreement coordinators regarding the pertinence, relevance and applicability of ICT in healthcare, education and management, as described in Chart 1.

Respondents fully agreed that these contents were pertinent, relevant and applicable in healthcare in teaching and management, with more than 7.5 points. The lowest mean was regarding applicability of content to the basic competence with 8.38, and highest, for the relevance of the contents for the development of the informational competence, with 9.81. One of the three competencies, informational, reached the highest mean score, with 9.28 , followed by information management, with 9.18.

Regarding the perception of the respondents for the inclusion of ICT content in the courses, they agreed that there is a large gap in this area. They described that the inclusion would be of the utmost importance, since the health worker process has its technological advances also in the field of cardiology, and has required nurses to develop skills and competencies related to ensure the continuity of their healthcare with quality excellence, following the example of the electronic health record and Systematization of Computerized Nursing Care.

Another perception described was that the ICT promote education, enhancing teaching-learning processes, representing breakthrough in distance education through the creation of virtual learning environments, where students, teachers and/or tutors have the ability to work in groups, debates, forums, and other ways to make learning more meaningful. Thus, the management of knowledge depends on the infrastructure and the will of each individual.

Chart 1 - Score of respondents from the Specialization and Residence courses in Cardiovascular Nursing - São Paulo, SP, Brazil, 2014.

\begin{tabular}{|c|c|c|c|c|c|}
\hline Content for basic competence & Pertinence & Relevance & $\begin{array}{c}\text { Healthcare } \\
\text { Applicability }\end{array}$ & \begin{tabular}{c|c} 
Teaching \\
Applicability
\end{tabular} & $\begin{array}{l}\text { Management } \\
\text { Applicability }\end{array}$ \\
\hline Concept of information and Communication Technology (ICT) & 9.46 & 9.37 & 8.79 & 9.16 & 9.08 \\
\hline Computer and managing files & 9.25 & 9.25 & 8.33 & 8.58 & 8.66 \\
\hline Text processing, spreadsheets & 8.83 & 8.58 & 7.83 & 8.50 & 8.66 \\
\hline Use of databases & 9.41 & 9.66 & 8.58 & 9.16 & 9.16 \\
\hline Graphical presentation & 9.25 & 9.50 & 8.41 & 9.08 & 9.16 \\
\hline Web browsing and Communication & 9.12 & 9.29 & 8.37 & 8.75 & 8.75 \\
\hline Mean & 9.22 & 9.28 & 8.38 & 8.87 & 8.91 \\
\hline \multicolumn{6}{|l|}{ Content for informational competence } \\
\hline Knowledge about the nature and extent of the information & 9.62 & 9.75 & 8.66 & 9.04 & 9.04 \\
\hline Access to information & 10.00 & 10.00 & 8.91 & 9.16 & 9.16 \\
\hline $\begin{array}{l}\text { Assessment of information and review selected sources in their } \\
\text { knowledge database and value system }\end{array}$ & 9.87 & 9.87 & 8.79 & 9.04 & 9.04 \\
\hline $\begin{array}{l}\text { Use of information for a specific purpose, either individually or as a } \\
\text { member of a group }\end{array}$ & 9.50 & 9.50 & 8.50 & 8.75 & 8.75 \\
\hline Creation of logical argument based on information obtained & 9.91 & 9.91 & 8.91 & 9.16 & 9.16 \\
\hline Mean & 9.78 & 9.81 & 8.76 & 9.03 & 9.03 \\
\hline \multicolumn{6}{|l|}{ Content for information management competence } \\
\hline Assessment of results of the use of information & 10.00 & 9.75 & 8.91 & 8.91 & 9.16 \\
\hline Importance of Health Information Systems for clinical practice & 10.00 & 9.75 & 8.91 & 8.91 & 9.16 \\
\hline $\begin{array}{l}\text { Knowledge of Health Information Systems and their clinical and } \\
\text { administrative purposes }\end{array}$ & 9.41 & 9.41 & 8.58 & 8.83 & 9.16 \\
\hline $\begin{array}{l}\text { Confidentiality of health information in the use of Information } \\
\text { Systems }\end{array}$ & 9.91 & 9.66 & 9.08 & 8.83 & 9.16 \\
\hline Access control of Information Systems in Health & 9.83 & 9.58 & 8.71 & 8.75 & 9.16 \\
\hline Security of Information Systems in Health & 9.75 & 9.50 & 8.71 & 8.75 & 9.16 \\
\hline $\begin{array}{l}\text { Principles on which are based on the organizational and } \\
\text { professional part of the Health Information System by health } \\
\text { professionals and consumers }\end{array}$ & 9.33 & 9.08 & 8.21 & 8.58 & 9.16 \\
\hline $\begin{array}{l}\text { User competencies, with navigation competencies, decision } \\
\text { support, reporting elaboration }\end{array}$ & 9.62 & 9.62 & 8.96 & 9.00 & 9.16 \\
\hline \multicolumn{6}{|l|}{ Others that are considered important: } \\
\hline Mean & 9.73 & 9.54 & 8.76 & 8.82 & 9.06 \\
\hline
\end{tabular}




\section{DISCUSSION}

The profile of the respondents points to the qualifications as CNRMS Resolution No. 2/12, which provides General Guidelines for Multidisciplinary Residence Programs and in Health Professional ${ }^{(17)}$ and Resolution No. 1/2007 which establishes detailed standards for running Specialization Graduate Courses ${ }^{(18)}$.

The highest number of Residence courses was in Public institutions, possibly due to the existence of scholarships as an incentive to the policy of Permanent Education of employees and/or because they facilitate their insertion in the world of work, while the course of Specialization was eminently private.

The student profile was evidenced in a similar way in both courses regarding healthcare, management and education dimensions with specificity for the cardiovascular area. It was found, however, that the Resident student profile is different due to their Research sphere, possibly because its development, which accounts for $80 \%$, occurs in the field, with evidence-based clinical practice, which strengthens the assertion that the evidence-based Nursing emphasizes the use of research to guide clinical decision-making, defined as the conscious, explicit and judicious use of information derived from research ${ }^{(19)}$.

The course coordinators considered that the inclusion of the contents would be of extreme importance, not as a specific discipline, as they should have been addressed at undergraduate level. They have the perception that the health worker process has its technological advances also in the field of cardiology, and it has required nurses to develop skills and competencies related to ensure the continuity of their healthcare with quality excellence, following the example of the electronic health record and Systematization of computerized Nursing Care, but that in practice there is a very large gap in this area. This gap in the training of technological skills possibly can be due to the low offer of classes at undergraduate level ${ }^{(5)}$, and by the difficulty of approaching knowledge applied to practice in health ${ }^{(8)}$.

This observation was found in international literature when experts, professionals from organizations and managing nurses were invited to demonstrate competencies in informatics ${ }^{(20)}$. We still verified gaps in the nursing curriculum for the development of these competencies ${ }^{(20)}$.

In a revision study conducted between 2000 and 2010(21), the emerging themes also pointed to gaps and the lack of consensus on what knowledge and skills about health informatics can be integrated in the bachelor's degree in nursing, with discussions about its impact on the results of healthcare to patients, faculty development with collaboration of organizations and global disparities in health informatics education in the syllabus of undergraduate courses.

Analyzing the 13 class plans from the Stricto Sensu Graduate programs in Nursing of Brazil containing informational competencies for management and nursing care, also found that there are content to the basic competence, but less content on competencies in the use of information and information management.
In this sense, pointing to the emerging need for inclusion of courses, classes of informatics in nursing in Graduate courses in Nursing Stricto Sensu, once the models proposed internationally already indicate the informational competencies and in information management, integrating informatics science and nursing ${ }^{(22-23)}$.

Advancing in the discussion of the contents offered by TIGER to Basic Concepts and Informational and Management Informational development, respondents fully agreed that these are pertinent, relevant and applicable in healthcare, in teaching and management. It is worth noting, however, that the score of applicability was lower in relation to the pertinence and relevance, and applied to healthcare was lower in relation to teaching and management, which requires future studies for understanding the reasons.

The contents of the informational competence were the ones which obtained the highest scores in all the criteria, perhaps pointing out that these contents are already being worked to develop evidence-based clinical expertise and documented in electronic records, as own proposition of the TIGER.

Technological skills applied to clinical practice have proven advantageous to nurses, and also to patients, pointing to evidence that these abilities, when properly used, can have a significant impact on the patients outcomes ${ }^{(24)}$.

Regarding electronic documentation of nursing in Brazil, this has generated reports of the nursing process, providing support to decisions. With the Organization and systematization of information in electronic systems, the operation of communication is facilitated to solve the problems of patients, demonstrating technical-scientific and human knowledge of nurses towards patient and the multi-professional team. This advance will make possible, in the future, simultaneous access to data by health professionals and organizations, improving patient care and favoring the development of healthcare and research protocols $^{(25)}$.

With regard to the content of the information management competence, we considered to be fully applicable to the management, which can confirm that the competencies training for the use of ICT is essential. The lack of access to the information or the lack of technological competence of the worker may involve its complete or partial exclusion in the decision-making process, which can trigger ethicalpolitical developments with institutional power relations ${ }^{(26)}$.

Finally, this study of teaching of technology in Specialization courses, mainly in Residence courses, supply the demand for permanent education in health policy that aims to integrate educational institutions and health services aiming at training practice transformations, attention to the process of work, and the construction of knowledge in the work and for work.

\section{CONCLUSION}

In this study, it was possible to identify that the Specialization and Residence Graduate Courses in Cardiovascular Nursing, Specialization in the city of Sao Paulo and Residence in Brazil, did not present in their curriculum the 
content or specific classes for ICT. This has been used as a tool for teaching and learning with views to the applicability for healthcare.

When considering that the Health or Multi-professional Residence courses occur in practical scenarios, the Permanent Education of attending, tutors or teachers, would be essential as these professionals, in their healthcare practice, combine their work in healthcare, management, teaching and research, and are not always provided with the competence in informatics.

The coordinators perceive gaps in training for undergraduate students, and recognize the need to include the content of ICT for the development of technological competence in specialized training of a cardiovascular nurse. However, there was the need of defining the content and informatics competence that should be developed in different levels of training of undergraduate and Graduate and also, in Vocational Professional Education.

With regard to content, these topics were considered applicable, pertinent and relevant with the highest mean for the informational competence. Despite this assessment, there is analysis of the lower applicability of the basic competence in healthcare, which will require studies to identify the reasons for this result, as well as for the determination of guidelines for minimum competencies and priorities at all levels of nursing education.

\section{RESUMO}

Objetivo: Identificar a percepção dos coordenadores dos Cursos de Especialização em Enfermagem Cardiológica sobre a inserção de conteúdos de Tecnologia de Informação e Comunicação (TIC) e analisá-los relacionando-os às competências tecnológicas e quanto à sua aplicabilidade, pertinência e relevância na assistência, ensino e gestão. Método: Estudo descritivo com 10 coordenadores do curso de Especialização em Enfermagem Cardiológica que responderam ao questionário para o desenvolvimento de competências tecnológicas adaptadas do modelo da Technology Initiative Guidelines Education Reforms (TIGER), e analisados utilizando a técnica de Delphi para obtenção de consenso e pontuados quanto à relevância, pertinência e aplicabilidade utilizando escala tipo Likert conforme grau de concordância. Resultados: Seis cursos desenvolviam conteúdos de TIC. Os conteúdos da TIGER foram considerados relevantes, pertinentes e aplicáveis. Conclusão: Os coordenadores reconhecem a necessidade da competência tecnológica do enfermeiro cardiológico visando à aplicabilidade assistencial.

\section{DESCRITORES}

Informática em Enfermagem; Conhecimentos em Informática; Enfermagem Cardiovascular; Tecnologia da Informação; Educação de Pós-Graduação em Enfermagem.

\section{RESUMEN}

Objetivo: Identificar la percepción de los coordinadores de los Cursos de Especialización en Enfermería Cardiológica sobre la inserción de contenidos de Tecnología de Información y Comunicación (TIC) y analizarlos relacionándolos a las competencias tecnológicas y en cuanto a su aplicabilidad, pertinencia y relevancia en la asistencia, enseñanza y gestión. Método: Estudio descriptivo con 10 coordinadores del curso de Especialización en Enfermería Cardiológica que respondieron al cuestionario para el desarrollo de competencias tecnológicas adaptadas del modelo de la Technology Initiative Guidelines Education Reforms (TIGER), con análisis mediante la técnica de Delphi para la obtención de consenso y puntaje en cuanto a la relevancia, pertinencia y aplicabilidad utilizando escala tipo Likert conforme al grado de concordancia. Resultados: Seis cursos desarrollaban contenidos de TIC. Los contenidos de la TIGER fueron considerados relevantes, pertinentes y aplicables. Conclusión: Los coordinadores reconocen la necesidad de la competencia tecnológica del enfermero cardiológico con vistas a la aplicabilidad asistencial.

\section{DESCRIPTORES}

Informática Aplicada a la Enfermería; Conocimientos en Informática; Enfermería Cardiovascular; Tecnología de la Información; Educación de Posgrado en Enfermería.

\section{REFERENCES}

1. Cavalcante RB, Pinheiro MMK, Watanabe YJA, Silva CJ. Grupo técnico de informação em saúde e populações: contribuições para a política nacional de informação e informática em saúde. Perspec Ciênc Inf. 2015;20(1):92-119.

2. Grossi LM, Pisa IT, Marin HF. Oncoaudit: development and evaluation of an application for nurse auditors. Acta Paul Enferm [Internet]. 2014 [cited 2015 June 16];27(2):179-85. Available from: http://www.scielo.br/pdf/ape/v27n2/en_0103-2100-ape-27-02-0179.pdf

3. Évora YDM, Fávero N, Trevizan MA, Melo MRAC. Evolução histórica da aplicação do computador na enfermagem (1965-1998). Acta Paul Enferm. 2000; 13(n.esp2):143-7.

4. Cardoso JP, Rosa VA, Lopes CRS, Vilela AVA, Santana AS, Silva ST. Construção de uma práxis educativa em informática na saúde para ensino de graduação. Ciênc Saúde Coletiva. 2008;13(1):283-8.

5. Sanches LMP, Jensen R, Monteiro MI, Lopes MHBM. Informatics teaching in undergraduate nursing programs at Brazilian public institutions. Rev Latino Am Enfermagem [Internet]. 2011 [cited 2014 Aug 18];19(6):1385-90. Available from: http://www.scielo.br/pdf/rlae/v19n6/15.pdf

6. Matsuda LM, Évora YDM, Higarashi IH, Gabriel CS, Inoue KC. Nursing informatics: unveiling the computer use by nurses. Texto Contexto Enferm [Internet]. 2015 [cited 2015 June 16];24(1):178-86. Available from: http://www.scielo.br/pdf/tce/v24n1/0104-0707tce-24-01-00178.pdf

7. Leite KNS, Santos SR, Andrade S, Zaccara AAL, Costa TF. A internet e sua influência no processo ensino-aprendizagem de estudantes de enfermagem. Rev Enferm UERJ [Internet]. 2013 [citado 2015 jul.21]; 21(4):464-70. Disponível em: http://www.facenf.uerj.br/v21n4/ v21n4a08.pdf 
8. Tanabe LP, Kobayashi RM. Profile, competencies and digital fluency of nurses in the Professional Improvement Program. Rev Esc Enferm USP [Internet]. 2013 [cited 2014 Aug 23];47(4):943-9. Available from: http://www.scielo.br/pdf/reeusp/v47n4/en_0080-6234reeusp-47-4-0943.pdf

9. Cruz NS, Soares DKS, Bernardes A, Gabriel CS, Pereira MCA, Évora YDM. Nursing undergraduates' technical competence in informatics. Rev Esc Enferm USP [Internet]. 2011 [cited 2014 Aug 23];45(n. spe):1595-9. Available from: http://www.scielo.br/pdf/reeusp/v45nspe/ en_v45nspea09.pdf

10. Vendruscolo C, Trindade LL, Prado ML, Luz JH, Dal Sasso GTM, Erdmann AL. A informática na formação e qualificação dos profissionais de saúde: uma revisão integrativa. Rev Enferm UFSM. 2013;3(3):539-46.

11. Technology Informatics Guiding Education Reform (TIGER). The TIGER Initiative. Evidence and informatics transforming nursing: 3-year action steps toward a 10-year vision [Internet]. 2007 [cited 2014 Aug 23]. Available from: http://www.thetigerinitiative.org/docs/ TIGERInitiativeSummaryReport_001.pdf

12. Hart MD. A Delphi study to determine baseline informatics competencies for nurse managers. Comput Inform Nurs. 2010;28(6):364-70.

13. Brasil. Ministério da Saúde; Rede Interagencial de Informações para a Saúde. Indicadores e Dados Básicos - Brasil - 2012. Vigilância de doenças crônicas não transmissíveis [Internet]. Brasília; 2012 [citado 2012 jul. 22]. Disponível em: http://tabnet.datasus.gov.br/cgi/ idb2012/matriz.htm

14. World Health Organization. World health statistics, 2011 [Internet]. Geneva; 2011 [cited 2012 June 26]. Available from: http://www.who. int/gho/publications/world_health_statistics/EN_WHS2011_Full.pdf

15. Technology Informatics Guiding Education Reform (TIGER). Informatics competencies for every practicing nurse: recommendations from the TIGER Collaborative [Internet]. 2006 [cited 2014 Aug 23]. http://www.thetigerinitiative.org/docs/tigerreport_informaticscompetencies.pdf

16. Keeney S, Hasson F, McKenna H. Consulting the oracle: ten lessons from the Delphi technique in nursing research. J Adv Nurs. 2006;2(53):205-12.

17. Brasil. Ministério da Educação; Secretaria de Educação Superior, Comissão Nacional de Residência Multiprofissional em Saúde. Resolução CNRMS n. 2, de 13 de abril de 2012. Dispõe sobre as Diretrizes Gerais para os Programas de Residência Multiprofissional e em Profissional da Saúde. Diário Oficial da União, Brasília, DF,16 abr. 2012. Seção I, p.24-5.

18. Brasil. Ministério da Educação; Conselho Nacional de Educação, Câmara de Educação Superior. Resolução CNE/CES n. 1, de 8 de julho de 2007. Estabelece normas para funcionamento de cursos de Pós Graduação Latu Sensu em nível de especialização [Internet]. Brasília; 2007 [citado 2015 jul. 20]. Disponível em: http://portal.mec.gov.br/cne/arquivos/pdf/rces001_07.pdf

19. Galvão CM, Sawada NO, Trevizan MA. Revisão sistemática: recurso que proporciona a incorporação das evidências na prática da enfermagem. Rev Latino Am Enfermagem. 2004;12(3):549-56

20. Hunter K, McGonigle D, Hebda T. The integration of informatics content in baccalaureate and graduate nursing education. Nurse Educ. 2013;38(3):110-6.

21. De Gagne JC, Bisanar WA, Makowski JT, Neumann JL. Integrating informatics into the BSN curriculum: a review of the literature. Nurse Educ Today. 2012;32(6):675-82.

22. Beckham R, Riedford K. Evolution of a graduate-level informatics course for the noninformatics specialist nurse. J Nurse Pract. 2014;10(6):387-92.

23. Jeungok C, Zucker DM. Self-assessment of nursing informatics competencies for doctor of nursing practice students. J Prof Nurs. 2013;29(6):381-7.

24. Bembridge E, Levett-Jones T, Jeong SYS. The preparation of technologically literate graduates for professional practice: a review of the literature. Contemp Nurse. 2010;35(1):18-25.

25. Oliveira NB, Peres HHC. Evaluation of the functional performance and technical quality of an Electronic Documentation System of the Nursing Process. Rev Latino Am Enfermagem [Internet]. 2015 [cited 2015 July 20];23(2):242-9. Available from: http://www.scielo.br/pdf/ rlae/v23n2/0104-1169-rlae-3562-2548.pdf

26. Kurcgant $\mathrm{P}$, Ciampone $\mathrm{MH}$. A formação de competências para o uso das tecnologias da informação e da comunicação na graduação em enfermagem. In: Prado C, Peres HHC, Leite MMJ. Tecnologia da informação e comunicação em enfermagem. São Paulo: Atheneu; 2011. p. 9-19.

Financial Support: Fundação de Amparo à Pesquisa do Estado de São Paulo (FAPESP). Process 2012/15437-2. 